\title{
On (Quasi-)Gnostic Strategies for Overcoming Cognitive Dissonance. The Bulgarian Case
}

A or those who study Gnosis, it would be a truism to claim that in its most
diverse forms Gnosticism can eliminate one of the most important and, at the same time, extremely taxing cognitive dissonances in monotheistic religions ${ }^{1}$ - the contradiction between the professed goodness of God the Creator and his omnipotence on the one hand, and the persistent presence of evil on the other. These aporias, unknown to polytheism, are set in the context of the fundamental ontological principle of the Judaeo-Christian tradition, namely the idea of an ethical and omnipotent Creator ${ }^{2}$. On the existential level, it is at odds with the human experience of suffering, which brings additional anguish to the mind that seeks a solution in rationalizations, sometimes only apparent, in hope of finding sense there. Some find solace in theodicy, others in the rejection of faith, while others still turn towards various variants of heterodoxy, carrying the promise of cognitive consonance ${ }^{3}$. However, there are not many possible combinations of religious ideas in the space of European cultures. In his book The Symbolism of Evil (La Symbolique du Mal, 1967, English translation 1969), Paul Ricoeur derives three types of symbolism from the vast material of Greek and Middle Eastern beliefs (still sense-making in Western theologies and anthropologies): the most archaic "tragic" vision (concerning the indistinguishability of the divine and demonic elements), "Adamic" (with its vision of an ethical God, symbols of the fall, the penitential rite and the concept of justification) and dualistic (with anthropological dualism, the symbolism of the exiled soul and the concept of self-redemption through cognition). According to Ricoeur, these models do not appear in pure form in the

\footnotetext{
${ }^{1}$ I use this term in the sense given to it by L. Festinger in his book A Theory of Cognitive Dissonance, Stanford 1957.

${ }^{2}$ L. Dupré, The Other Dimension. A Search for the Meaning of Religious Attitudes, Garden City 1972, p. 334-352.

${ }^{3}$ From an individual perspective, the spectacular record of this process of negotiating meanings was given by Carlo Ginzburg in his book Il formaggio e i vermi (Torino 1976, English title: The Cheese and the Worms, 1980).
} 
human religious imagination, and archaic symbols derived from ancient imagery are mutually correlated in a constant "cycle of the myths", where a tragic vision is always something possible, where every crisis triggers temptation to openly or secretly revitalize archaic theogony (for example in its Greek or Babylonian version). As Ricoeur argues, the "Adamic" myth of the fall needs the other two, so that the ethical God it presupposes may continue to be a 'Deus absconditus' and so that the guilty man it denounces may also appear as the victim of a mystery of iniquity which makes him deserving of Pity as well as of wrath ${ }^{4}$.

Following in the footsteps of Walter Benjamin, who regarded the "dwarf of theology" as a hidden moderator of every (seemingly rational) discourse ${ }^{5}$, one can use an even more far-reaching visualization of the phenomena described by Ricoeur and put forward a hypothesis that "under the table" of each of the theologies "dwarfs" of other "theologies" can also be hiding, in the case in question - of (quasi-)Gnostic theologies. Contemporary postsecular thought has already done much both to uncover the religious basis in the writing of individual authors and in seemingly non-religious ideological and philosophical paradigms, often unaware of their own genealogy ${ }^{6}$. However, I would like to start my further reflection with a piece by the German researcher of political and pedagogical theories, Micha Brumlik, entitled Die Gnostiker. Der Traum von der Selbsterlösung des Menschen (1992). The author's aim in this treatise is, as he himself says, "therapeutic":

I am interested in examining whether we can confirm the assumption that turning away from the reality of this world and seeking redemption in another world with all the determination through higher knowledge, even when, or rather precisely when this very search results from a fundamental criticism of power and law, with some strange necessity turns into even harder power and violence. Starting with the anti-Jewish and nationalist philosopher J.G. Fichte, through the anti-Semitic opera composer Richard Wagner, to the depth

\footnotetext{
${ }^{4}$ P. Ricoeur, The Symbolism of Evil, trans. E. Buchanan, Boston 1969, p. 346.

${ }^{5}$ It is well-known that an automaton once existed, which was so constructed that it could counter any move of a chess-player with a counter-move, and thereby assure itself of victory in the match. A puppet in Turkish attire, water-pipe in mouth, sat before the chessboard, which rested on a broad table. Through a system of mirrors, the illusion was created that this table was transparent from all sides. In truth, a hunchbacked dwarf who was a master chess-player sat inside, controlling the hands of the puppet with strings. One can envision a corresponding object to this apparatus in philosophy. The puppet called "historical materialism" is always supposed to win. It can do this with no further ado against any opponent, so long as it employs the services of theology, which as everyone knows is small and ugly and must be kept out of sight, W. Benjamin, On the Concept of History, New York 2009, p. 2.

${ }^{6}$ There is a wealth of literature on the subject of Gnostic roots of many ideas that give a recognizable rhythm to particular literary currents, philosophies and ideologies in Western culture (see The Experience of Faith in Slavic Cultures and Literatures in the Context of Postsecular Thought, ed. E. DrzEWIECKA, D. SosnowsKa, Warszawa 2018). It is worth mentioning the classic works of E. Voegelin, L. KoŁakowski, J. Taubes, G. Agamben. An overview of the most important views in the field of political theology can be found for example in Merio ScATOLLA's book Teologia politica, Bologna 2007.
} 
psychologist G.C. Jung and philosopher Martin Heidegger, both eagerly embracing National Socialism, or even the political lawyer and thinker Carl Schmitt, who denied Gnosis but considered it true in the depths of his mind, we become witnesses time and again to the fact that the fruit born of harsh criticism of the fallen world is not love and gentleness, but, on the contrary, pure hatred. ${ }^{7}$

Brumlik exposes the Gnostic pattern in the reasoning of right-wing Germanlanguage philosophical and theological thought of the nineteenth and twentieth centuries, but also shows its presence in the representatives of left-wing and liberal thought. He reconstructs the intellectual processes that in Germany led to revitalization of such Gnostic strategies of self-redemption, which in specific authors are associated with the externalization of evil (and thus with the angelization of the "I" - one's own community, worldview formation, etc.) and the establishment of the imperative to repair the world by "cleansing it" of strangers, of "servants of the evil god", which in the public sphere took the form of anti-Semitism.

Brumlik's position is the result of an analysis of culture understood not as a static palimpsest, but as a vibrant coexistence of modern and pre-modern rules of reasoning, which permeate the logic of great, albeit not infallible minds. The researcher poses an important question about the significance of the cultural context for the selection of specifically (quasi-)gnostic strategies for dealing with the problem of the presence of evil in the world. In its heterogeneity and associativeness, colloquial thinking turns out to be the carrier of ideas that has a powerful culture-making potential ${ }^{8}$. In short: according to Brumlik, in the thinking of the aforementioned coryphes of German culture, the uprooted model of Gnostic dualism is correlated with the Gnostic aspects of Protestantism ${ }^{9}$ and socialism ${ }^{10}$. As a result of their meeting, the tendency to perceive the world in binary terms is strengthened; the alleged ontological dualism is pseudo-rationalized:

The history of gnosis so far leaves no doubt as to its anti-Jewish character, yet only a few of the ancient and medieval Gnostics marked themselves as enemies of the Jews. [...] Only

\footnotetext{
${ }^{7}$ M. Brumlik, Die Gnostiker. Der Traum von der Selbsterlösung des Menschen, quote based on the Polish edition, Gnostycy. Marzenie o samozbawieniu człowieka, trans. Ś.F. NowICKI, I. NowickA, Gdańsk 1999, p. 19-20.

${ }^{8}$ In the 1930s, Ludwick FLECK wrote about achievements inspired by the folk concept of "bad blood" (Entstehung und Entwicklung einer wissenschaftlichen Tatsache. Einführung in die Lehre vom Denkstil und Denkkollektiv, 1935, published in Polish as Powstanie i rozwój faktu naukowego, Warszawa 1986). Many years later Thomas Kunn developed this idea in his book The Structure of Scientific Revolutions (Chicago 1962).

${ }^{9} \mathrm{M}$. Brumlik does not mention them all, but it could be about iconoclastic orientation, predestination, rejecting the concept of transubstantiation.

${ }^{10}$ Eric Voegelin wrote most extensively about the Gnostic roots of socialism in his book From Enlightenment to Revolution (1975, Polish ed. Od oświecenia do rewolucji, Warszawa 2011), but this thought was also present in the works of many other philosophers and researchers of the history of ideas, including Leszek Kołakowski.
} 
in combination with the modern philosophy of free subjectivity, which bears the mark of Protestantism, and the early socialist themes of salvation from the financial economy found in Fichte, Wagner, Jung and Heidegger, does the Gnostic legacy release its destructive power. In the idea of salvation through destruction, in the idea of the twilight of the gods, which condenses the powers of technology, intellect, law and money in the image of the Jew and then annihilates them, a program is formed that only needs a decisive savior to execute it literally. ${ }^{11}$

In the twentieth century, marked by the experiences of the First and Second World Wars and, above all, the Holocaust, the fear of a repetition of the hecatomb gave rise to the need to reflect, among other things, on the sources of those mechanisms of reasoning which made it easier for ordinary people to accept violence, providing their own consciences with an appropriate alibi. The variant of the "archaeology" of the cultural sources of German anti-Semitism presented here can, of course, be considered partial and underpinned with anti-Protestant prejudice. Brumlik's book is worth mentioning, however, as it inspires us to pose research questions also in relation to other source materials, e.g. national imaginaries built on the foundations of Roman Catholicism (and, for example Polish, Spanish, Slovak or Hungarian cultural language) or Orthodoxy (Romanian, Russian, Greek and others). Indeed, anywhere the multifunctional phantasm of "the Jew - the servant of the evil god" has been established, equally available to various (also mutually hostile) secular ideologies of "self-redemption" (Fascism, Communism, even diachronically understood liberalism). The Polish culture, which in one of its branches at the level of popular political thought uses fables blaming Jews for all the misfortunes that have befell the Polish nation befall it in the future ${ }^{12}$ (starting with accusations of ritual murder ${ }^{13}$, through the misdeeds of capitalists, communists, liberals, to representatives of "gender ideology" and LGBT), provides disgraceful examples in this respect. I think that in this context the reasoning of Brumlik and other trackers of the Gnostic origin of the figure of the "servant of the evil god" can be functional on the grounds of the so-called engaged humanities, which for the last two decades have seemed to be a kind of a swan song of a discipline eliminated from the world of increasingly conflicting worldviews.

The Gnostic division of people into three (pneumatics, psychics, hylics) and sometimes two (pneumatics, hylics) groups stemmed from the belief that the

\footnotetext{
${ }^{11}$ M. BRumlik, Die Gnostiker..., p. 298-299.

${ }^{12}$ In Poland, anti-Semitism was traditionally the strongest in the west of the country, where there were few Jews and where the imbalance between Jews and non-Jews in various professions was much less pronounced. As we will see, the anti-Semitism promoted by National Democrats went beyond any rational economic postulates or specific problems and quickly turned into a chimeric hatred aimed at freeing Poland from the alleged 'Jewish domination', P. BRYKCZYŃsKI, Gotowi na przemoc. Mord, antysemityzm i demokracja w międzywojennej Polsce, Warszawa 2017, p. 12.

${ }^{13}$ See J. Tokarska-Bakir, Legendy o krwi. Antropologia przesadu, Warszawa 2008. In reference to post-war Poland: EADEM, Pod klątwa. Społeczny portret pogromu kieleckiego, Warszawa 2018.
} 
human soul was imprisoned in matter and only when liberated from this trap would it be possible for it to return to a true life of unity with God. Not all people, however, were predestined to do so. The pneumatics were considered ideal for this path, for the psychics there was a chance, provided they follow strict rules of asceticism, and the hylics were deprived of such an opportunity. As people of the earth, not possessing God's spirit, servants of mammon, they were a despised mob, "righteously" hated and condemned to nonexistence for eternity. As twentiethcentury researchers interested in the quasi-Manichaean foundations of Marxism and Fascism argued, hylics could have had many incarnations...

\section{The Bulgarian case - "Servants of the Evil God"}

As we know, as far as modern functionalizations of Neognosticism are concerned, Bulgarian culture, which is the main focus of this text, seems a peculiar case in point. In the Middle Ages, many inhabitants of the Balkans went through a phase of Neognostic dualism that lasted for several centuries: in Bulgaria, under the name of "Bogomilism" from the tenth to - at least - the seventeenth century. And although historians are generally of the opinion that the Bogomil movement gradually ceased to exist, the young Bulgarian intelligentsia, on the wave of nineteenth century modernization, revived (not without the influence of foreign scholars and Protestant theologians) the social memory of that formation. Although Bulgarians entered modernity as followers of Orthodoxy, in the period when modern national consciousness was being formed, Bogomilism was introduced into the canon of national culture as a postulated element of tradition. In my paper Bogomilism. The Afterlife of the "Bulgarian Heresy" (Polish edition 2005, Bulgarian - 2010, English - 2017), to which this article is a postscript of a kind, I have analyzed such texts of nineteenth and twentieth century Bulgarian culture, in which Bogomilism was explicitly referred to and emphasized in such a way as to make it a probable forerunner of various ideas, important in the changing historical context. Such an anachronism was fostered by the vagueness of the image of Bogomilism, because the original Orthodox Slavic sources have not survived, nor, as I have mentioned, has it survived as a religious community until modern times. The system of beliefs was reconstructed by means of anti-heretical literature, apocrypha, Qatar documents and native folklore. With time, playing the Bogomilism card has become an element of social strategies of negotiating political and philosophical meanings. As a result, over the last two centuries, progressively oriented authors have interpreted Bogomilism as a precursor of Reformation and Enlightenment, antifeudal movements, Western rationalism, humanism, freemasonry, socialism, folk democracy, agrarianism, liberalism, syncretic spirituality of the New Age, or even feminism. These trends of ideological or religious persuasion permeated the literature, painting, journalism, scholarly and quasi-scholarly texts, school textbooks, etc. In carefully selected staffage, Bogomilism has become a tool for the strategy 
of adapting Bulgarian culture to Western civilization. What is new and foreign was presented as familiar and old, well rooted in the past, because it was attributed to the commonly accepted "heretical" identity of Bulgaria. As a result, the ideas of Western civilization associated with modernization were presented as embedded in the native history, and medieval Bulgaria could thus become their mother country, which, of course, increased the prestige of the native tradition not only in its own eyes ${ }^{14}$.

In the various concepts of Bulgarian religious missionism (esoteric - paraGnostic, Orthodox) and the Enlightenment (rational) one, texts proclaiming the precursors of the Bogomils annihilated their alleged primordial ontological dualism $^{15}$. This fact says as much about the adaptability of Bulgarian culture as it does about the axiological orientations of modernity. It carried a powerful soteriological impulse (mainly in the form of the idea of progress ${ }^{16}$ ). By committing a kind of "betrayal" of the suspicion - fundamental for Neognosticism - of the material world, carnality, everything mundane, Bulgarian culture probably defended itself against Manichaean nihilism this way. And only some writers of the interwar right wing milieu rejected this tendency, blaming Bogomilism for the Bulgarians' hostility towards the state and, as a result, for "national disasters" ${ }^{17}$. Meanwhile, representatives of ideologies oriented towards civilizational progress (liberalism, socialism, communism, agrarianism) or those interested in "spiritual" progress (White Brotherhood, New Age) usually ignored the consequences of the negative attitude of Bogomils towards the material world (e.g. food and sexual asceticism, rejection of power, wealth), and above all rejected their skepticism about the chance to heal the reality ${ }^{18}$. The image of matter as the domain of Evil was at odds with the repair projects based on the affirmation of the mundane world. That is why in place of the Gnostic pessimism, asceticism and contempt for the people of "the earth" (hylics identified with power and wealth) Bogomils were attributed the faith in progress in history, vitality, and humanism.

\footnotetext{
${ }^{14}$ In Poland, this role (although to a much lesser degree) is played by Zbigniew OGonowski's book Socynianizm. Dzieje, poglady, oddzialywanie (Warszawa 2015), which corresponds to the achievements of historians of ideas raising the significance of Arianism for the so-called radical wing of the European Enlightenment (see J. IsraeL, Radical Enlightenment. Philosophy and the Making of Modernity 1650-1750, Oxford 2002).

${ }^{15}$ G. Szwat-GyŁybowa, Haeresis bulgarica w bułgarskiej świadomości kulturowej XIX i XX wieku, Warszawa 2005, p. 290-297.

${ }^{16}$ See J. TAubes, Apokalipsa i polityka. Eseje mesjańskie, Warszawa 2013. For Bulgarian culture, see G. Szwat-Gyєy воwa, Playing Catch up: The Notion of Needing to Accelerate a Country's Progress Towards a Civilised Paradise - The Bulgarian Version, SMer 14, 2014, p. 310-328.

${ }^{17}$ A good example are the historical essays by Petyr Mutafchiev.

${ }^{18} \mathrm{G}$. Quispel emphasized the indifference to ethics as a fundamental characteristic of Gnosticism and interpreted it as a result of the disgust of Gnostics towards the cosmic and moral law granted by Demiurge, which he perceived as a very sensitive gap in Gnosis, which cannot be filled either by hatred for the world or by libertinism. See G. Quispel, Gnoza, Warszawa 1988, p. 79.
} 
Thus, the Gnostic tradition, alienated from itself, equipped with unusual attributes and translated into the system of concepts of the new universe, became an element of the invented tradition. Especially in the twentieth century, it suggested a solution to the problem of confessional affiliation, providing arguments for valuing heterodoxy, which was undertaken by many talented Bulgarian writers (such as Emilian Stanev, Blaga Dimitrova, Anton Donchev or Stefan Tsanev). They did not create a monolithic vision of haeresis bulgarica, but the common denominator in their case was the perception of historical Bogomilism as a culturally significant attempt to deal with the common cognitive dissonance resulting from the presence of evil in the world. Heroes of their books usually defined evil as material poverty, abuse of power, violence, lies, etc., and did not avoid depreciating "servants of the evil God". In modern Bulgarian literature, depending on their intentions, they could be rich, members of the clergy, capitalists, Bulgarian intelligentsia, kulaks, fascists, communists, anti-communists, plebs, state security service officers, but also Greeks, Turks, Latin Americans, etc.

It is a paradox that although the propaganda of the Bulgarian nationalists of the interwar era oscillated around the chimera of the "Jewish threat" and the state introduced anti-Semitic laws, until the end of the twentieth century such a figure of a "Jew" was not established, either in Bulgarian literature or in the collective imagination (including its allegory, sanctioned on the grounds of anti-Semitism - namely that of Judas ${ }^{19}$ ), which could become a link that would integrate the order of thought dominating the current of the Bulgarian national imagined community.

\section{The Bulgarian case. Judeophobia or anti-semitism?}

In the nineteenth century, nation-building processes forced a situationally conditioned distribution of accents; in the political game it was first a matter of appreciating the language and literature as a national treasure (it this case it involved convincing the people), then the autonomy of the Orthodox Church (here the Greeks were denigrated), and then independence (here the "Turkish oppressor" was demonized). In the then ethnocultural mosaic of the Ottoman Empire dominated by Bulgarians, the Jews, as a minority, did not play any major role ${ }^{20}$. This did not mean the absence of religious, ethnic, economic or political antagonisms. In the deepest layers of Bulgarian folklore, which until the nineteenth century was often the only source of social and moral norms for the overwhelming majority ${ }^{21}$,

\footnotetext{
${ }^{19}$ E. Drzewiecka, Herezja Judasza w kulturze (ponowoczesnej). Studium przypadku, Kraków 2016.

${ }^{20}$ С. РАЙчевски, Бблгари и евреи през вековете, София 2008. An extensive thematic bibliography has been collected in the volume: Евреите по българските земи. Анотирана библиограбия, ed. Ж. ЕСКЕНАЗИ, А. КрИСПИН, София 2002.

${ }^{21}$ T. DĄBEK-Wirgowa, O antynomii swoi - obcy z perspektywy bułgarskiej, [in:] Kategorie peryferii i centrum w kształtowaniu się kultur narodowych, ed. T. DĄBEK-WIRGowa, J. WiERzBICKI, Warszawa 1986.
} 
researchers found negatively charged themes of the "yellow Jew" accused of usury, betrayal of Christians, bodily impurity, etc. ${ }^{22}$ The question about the origin of antiJewish stereotypes remains open. We should probably take into account a multiple sources and a migration of themes. The image is made more complex by the fact that the Jewish community in those areas was neither numerous nor homogeneous and consisted of autochthons (the so-called Roman Jews), Sephardic Jews - refugees from the Iberian Peninsula and Ashkenazi Jews, who settled there only in the nineteenth or even twentieth century ${ }^{23}$. The five-hundred-year Ottoman rule, when this religious group enjoyed a relatively high position in the empire as a people of the Book and Law living within its own cemaat, left behind a moderate economic Judeophobia ${ }^{24}$. At the same time, the source of anti-Judaism was the Orthodox Church, which disseminated the image of the Mosaic religion as an unclean or even demonic faith, which was served, among other things, by stories about the ritual murders allegedly committed by Jews against Christian children ${ }^{25}$. In modern Bulgarian studies, the Greek clergy is sometimes held responsible for spreading such rumors ${ }^{26}$. After all, the image of a Jew feeding on the blood of innocents had appeared in the texts of culture before the Greek Megali Idea came to the fore; it can be found in many Orthodox Slavic manuscript collections of mixed content dated between the seventeenth and nineteenth centuries (including the writings of Neofit Bozveli) ${ }^{27}$. In the nineteenth century, when new periodicals were becoming more and more widespread, the theme was reproduced in the press, but (which is worth noting) the Ottoman authorities usually repudiated such reports.

Many contemporary bring out the foreign origin of anti-Jewish superstitions and responsibility for their researchers inculturation by blaming nineteenth century Bulgarian emigrants, who brought with them their experiences and obsessions from Wallachia, Moldavia or Russia. For example, Rumen Genov formulates the idea that anti-Semitism was introduced to Bulgaria on the wave of modernization and (like everything else) had an imitative character ${ }^{28}$. Petj Nedelev's classification of this phenomenon is similar, claiming that it has a European origin: These typical examples of accusations of a 'ritual murder' are no different from the anti-Jewish phenomena, in Europe from where they were brought here ${ }^{29}$.

\footnotetext{
${ }^{22}$ О. ТодоровА, Образбт на “нечестивия евреин” в българската книжнина от XVIII - началото на ХІХ век и във фолклора, ВF 3, 1994, р. 10-21.

${ }^{23}$ П. НеДЕЛЕвА, Място и роля на еврейската общност в българските земи (от османско владичество до 30-те години на хх в.), ЮСНБУ 2, 2013, р. 33-58.

${ }^{24}$ O. Todorova, The Nineteenth-Century Bulgarians' Perception of the Jews, EB 1995.3-4, p. 40-41.

${ }^{25}$ О. Тодорова, Евреите в българската словесност от началото на ХІХ век до Освобождениеmo, http://www.librev.com/index.php/discussion-bulgaria-publisher/1759--ix-.

${ }^{26}$ П. НеДЕЛЕвА, Място и роля..., р. 43.

${ }^{27}$ О. Тодорова, Евреите в българската словесност...

${ }^{28}$ Р. ГЕнов, Дизраели, Еврейството и антисемитизмът в България, http://dialogueeurope.org/ uploads/JewsCol/Panel101.pdf, p. 24.

${ }^{29}$ П. НеДЕЛЕвА, Място и роля..., р. 49.
} 
Biographies of many activists of the national rebirth era confirm this notion (at least in part); for example, the Russian-Romanian formation of the anarchosocialist Christo Botev, who vented his hatred towards Jews - bankers and capitalists - in his journalism. We also cannot ignore the inspiration of Russian antiSemitism in the writings of Lyuben Karavelov, who in a single text managed to demonstrate his admiration for the culture of everyday life of Balkan Jews and contempt for Sophia Jews (Записки за България и Българите) ${ }^{30}$. The emotions documented in such articles seem to have had some background in social life. The years of the Russian-Turkish war (1877-1878) brought about a wave of pogroms in several cities in Bulgaria (including Kazanlak and Stara Zagora). The purpose of the bloody violence was to loot the goods. The riots usually began shortly before the Russian army entered the cites, and continued with the participation of soldiers' it was preceded by rumors of Jewish betrayal of the Bulgarian people and espionage for the benefit of the Turks ${ }^{31}$. However, the catalyst for nationwide antiJewish rhetorical raptures was the events that took place after the war, associated with the political activity of the British Prime Minister Benjamin Disraeli. The abolition of the Treaty of San Stefano ${ }^{32}$ in favor of the solutions adopted by the Berlin Congress, which were less favorable to Bulgaria (1878), was interpreted by the Bulgarian elite as a result of the anti-Bulgarian policy advocated by Disraeli, whose Jewish descent became the basis for anti-Semitic narratives, not just in the press ${ }^{33}$. At the time, the future coryphe of Bulgarian literature, Ivan Vazov, employed hare speech with no qualms - he did not spare the British official any insult ("бездушният жид”, „циничният”, “зверовит”, “лъжлив”) in the series of poems Tъгите на България, placing him among a plethora of villains. Vazov found relief in his conspiracy theory; such pseudo-rationalization helped him to deal with the cognitive dissonance caused by the change in public opinion's attitude towards Bulgaria. In several of his later texts he also returned to figure of the "treacherous Jew", which was to become the key to the mythologized interpretation of Bulgarian history from

\footnotetext{
${ }^{30}$ This writer, unstable in his choices, drew inspiration from Russian sources in this regard. The Mercurean aspect of his ideological borrowings was revealed by Olga Todorova and Keta Mirchevana on the sidelines of the reconstruction of the biography of the British-Osman adventurer (who first served the Ottomans, and later Russians, among others), Friderick Millingen (a.k.a. Osman bey), whom Karavelov met. This important footnote to the history of ideas in the dynamic nineteenth century shows the simultaneity of the phenomena mentioned here, which does not rule out their seriousness, when the subject of action is a socially active intelligent, capable of using the tools of persuasion in the process of externalization of evil. See О. Тодорова, К. МирчевА, Фамилията Милинген и българите през третата четвърт на ХІХ век, https://www.marginalia.bg/aktsent/ familiyata-milingen-i-balgarite-prez-tretata-chetvart-na-hih-vek/.

${ }^{31}$ B. Rusin, Ekscesy antyżydowskie na ziemiach bułgarskich Imperium Osmańskiego w czasie wojny rosyjsko-tureckiej 1877-1878, http://apcz.umk.pl/czasopisma/index.php/SDR/article/view/SDR.2016.1.01. ${ }^{32}$ И. Илчвв, Митгт за Сан Стефанска България като "свещена крава" на българския национализбм, http://www.segabg.com/online/new/articlenew.asp?issueid=1486\&sectionid=8\&id=00003/.

${ }^{33}$ Р. Генов, Дизраели, Еврейството..., р. 24-29.
} 
the Middle Ages to the present day. In the novel Иван Александър (1907) and the historical drama Kż nponacm (1909) Vazov made Sara - the Jewish wife of Tsar Ivan Alexander - guilty of the scheme that brought about the fall of the second Bulgarian Empire and, as a result, the Ottoman captivity. Although this concept is not well established in the collective consciousness of Bulgarians as a self-reproductive and credible model for the interpretation of history, the writings of Vasov (a Russophile, liberal and Anti-Semitite) contributed to the rise in the temperature of anti-Jewish sentiments, not just among the intelligentsia.

Meanwhile, in the non-textual reality, in several ethnically mixed Bulgarian cities (Pazardzhik, Vratsa, Lom, Kyustendil) in 1884-1904 there were trials held for Jews accused of ritual murder ${ }^{34}$. The turn of the nineteenth and twentieth centuries saw the appearance of anti-Semitic brochures by Krum Mitakov (е.g. България за Българите); his clumsy ideas were continued in the rhetoric of the interwar era, primarily in the propaganda of the far right (including the organization Ратник), but also in the "philosophical" racist thought fueled by eugenic ideas ${ }^{35}$. Nationalist, para-fascist and fascist formations that were developing at that time enjoyed the support of the state, which implemented pro-German policy. The legislative act that sanctioned open state anti-Semitism was the Law on the Protection of the Nation (Закон за защита на нацията), which came into force in January 1941 (обн., ДВ, бр. 16 от 23.01.1941 г.), where the second chapter was devoted to the restrictive "regulation" of the situation of Jews in Bulgaria ${ }^{36}$. Although by 1943 the Bulgarian Parliament adopted seven more anti-Jewish laws ${ }^{37}$, the planned transports of Bulgarian Jews to death camps stopped in $1943^{38}$. In Bulgarian historiography, for many decades this has been the crowning argument for the notion that Bulgaria is unique as a country without any anti-Semitism, except maybe for something that could at the most be seen as an insignificant marginal peculiarity. As the research on the Holocaust progressed, this auspicious image was blurred

\footnotetext{
${ }^{34}$ V. TAmir, Bulgaria and Her Jews. The History of a Dubious Symbiosis, New York 1979, p. 118.

${ }^{35}$ The talented Bulgarian poet, a Germanophile and a Germanophobe in one, and at the same time an epigone of Modernism, Kiril Christov on the wave of racist theories and eugenics created his own concept of races in the 1920s. In his treatise От нация към раса (1929), he placed the multiethnic origins of the Bulgarian nation higher than the Jewish racial purity. In constructing pseudo-scientific certainties, he interpreted the latter as a source of degeneration of Jews deprived of their life force and effeminate, and praised the native blood mixture as conducive to physical vigor. К. Христов, От нация към раса, УП 8, 1929.

${ }^{36}$ Д. Токушев, Антиеврейското законодателство и неговото преодоляване (1942-1945 г.), София 2010; П. НЕделЕвА, Антиеврейското законодателство в България през Втората световна война, София 2013; И. ГезЕнко, Законодателната и изпвлнителната власт в изграждането на антиеврейското законодателство 1940-1944 г..., [in:] Обречени и спасени. България вантисемитската програма на Третия райх. Изследвания и документи, София 2007.

${ }^{37}$ 3. КръстевА, Правни аспекти на държавната антиеврейска политика в Царство България (1940-1944 г.), Берлин 2018.

${ }^{38}$ Оиеляването 1940-1944 (The Survival 1940-1944), ed. D. Cohen, Sofia 1995.
} 
by the results of archival explorations, revealing, among other things, the fact that historians had long denied that the Bulgarian state was responsible for the deportation of Jews from the so-called occupied areas of Macedonia and Thrace ${ }^{39}$.

\section{The Bulgarian case - pneumatics without hylics?}

In her collection of essays Ти вярваш. Осем погледа върху Холокоста на БалкаHume (2012) Lea Cohen points out that the author of the internationally held view of Bulgarians' uniqueness and their attitude towards Jews during World War II was Hannah Arendt. Since the publication of her work Eichmann in Jerusalem. A Report on the Banality of Evil (1963) it has been very controversial; paradoxically, the Bulgarian voice now feeds into this critical current. When writing several pages about the situation of Jews in Bulgaria during World War II, Arendt used Raul Hilberg's book The Destruction of the European Jews (1961), but the point formulated by her was a kind of memorate based on the logic of association:

\footnotetext{
I know of no attempt to explain the conduct of the Bulgarian people, which is unique in the belt of mixed populations. But one is reminded of Georgi Dimitrov, a Bulgarian Communist who happened to be in Germany when the Nazis came to power, and whom they chose to accuse of the Reichstagsbrand, the mysterious fire in the Berlin Parliament of February 27, 1933. He was tried by the German Supreme Court; [...]. His conduct was such that it won him the admiration of the whole world, Germany not excluded. 'There is one man left in Germany,' people used to say, 'and he is a Bulgarian.'.0
}

In a historically mutable mode of appropriation of claims to merit for "Deliverance" (so-called in Bulgarian political historiography), Lea Cohen captured a significant sequence of shifts. Until the end of the so-called communist regime, the leading role (following Hannah Arendt's "recognition") was assigned to Bulgarian communists; in personal terms - to Todor Zhivkov. After 1989, the mantle of the chief defender of the Jews was taken by Tsar Boris III (in a way contrary to political logic and historical facts). Others also attempted to seize the temporarily vacant position for themselves, including even the White Brotherhood (Cohen does not even mention this), who tried to make Peter Dynov, founder of the occult school of Bulgarian Neognostics, a protector of the Jews. Finally, the turn came for the entire Bulgarian nation as the one who opposed the political intentions of the decision-makers and, through collective and individual acts of resistance, hindered their execution ${ }^{41}$. However, as Cohen observes, this glorification of the nation (essentialized on the model of the nineteenth century idea and, let us add, angelized in the Gnostic spirit as a community of "ideal" people) was accompanied

\footnotetext{
${ }^{39}$ Депортирането на евреите от Вардарска Македония, Беломорска Тракия и Пирот. Март 1943 z., vol. I-II, ed. Н. ДАНОвА, Р. АвРАмОв, София 2013.

${ }^{40} \mathrm{H}$. Arendt, Eichmann in Jerusalem. A Report on the Banality of Evil, London 2006, p. 186.

${ }^{41}$ This is the direction of the selection of source materials in: Оцеляването 1940-1944...
} 
by parallel rehabilitation of a number of historical figures in the background (such as, for example, Bogdan Filov or General Lukov) and organizations (such as the fascist Съюз на българските национални легиони, Ратник, Бранник), which were considered as "victims of communism", condemned by the People's Court for fighting left-wing totalitarianism and thus for defending native values. Thus, already in the 1990s, the Bulgarian society was offered a standard process of replacing the figures of villains (in Brumlik's language: "servants of the evil god", Gnostic hylics) and victims (respectively: pneumatics) as founding ideologues of the new reality, thereby instrumentalizing the case of Bulgarian Jews.

Today's research on anti-Jewish activities of Bogdan Filov's government from the introduction of the anti-Semitic Law on the Protection of the Nation in 1941 to the death of Boris III in 1943 reveals a more complex image than any of the political options that idealize the past would like to see. In his treatise "Cnaceние" и падение: Микроикономика на държавния антисемитизбм в България 1940-1944 2. (2012), Rumen Avramov called this phenomenon "state economic anti-Semitism" ${ }^{42}$, pointing to the organized, systemic nature of activities under the patronage of specific institutions and their heads, such as Alexander Belev (1900-1945) - anti-Semitic supporter of the extermination of Jews, co-founder of the fascist organization Ратник, legal counsel of the Holy Synod of the Bulgarian Orthodox Church, the main commissioner of the aforementioned Committee for Jewish Affairs and, above all, the decision-maker in matters concerning the Jewish property seized by the state. In his study, Avramov shows the documents of depravities committed in the first place by people representing the Bulgarian elite - clergy, teachers, officials of all levels, lawyers, university lecturers, journalists, writers, etc. Using their personal acquaintances with people in power, they sought to improve their material status by asking them to grant them "post-Jewish" property (they usually used euphemisms in their applications, e.g. "the property in question", "abandoned apartments", etc.). The movable property of the displaced Jews, on the other hand, raised hopes for profit for village dwellers, who took care of their own business in a less sublime way, coming to larger towns with wagons ready to load the necessary items. Avramov's analysis reveals the economic basis for anti-Semitic attitudes, where a passive attitude towards anti-Semitic state policy went hand in hand with greed and readiness to take advantage of the opportunity to legally allow someone else's property to be appropriated. It was faced with a psychological mechanism of legitimizing one's own attitudes in the socially sanctioned act of denigrating the victims. As Avramov rightly points out, this aspect of the looting of Jewish property prepared the ground for the looting of the bourgeoisie property ${ }^{43}$, which took place only several years later under the communist regime.

${ }^{42}$ Р. Аврамов, “Спасение" и падение. Микроикономика на държавния антисемитизъм в България 1940-1944 г., София 2012, р. 264.

${ }^{43}$ Ibidem, p. 179-181. 
At the same time, there are more and more arguments to support the thesis that the Holy Synod of the Bulgarian Orthodox Church in 1940-1944 was the only official institution that conducted consistent efforts to reject the state racist policy of violence ${ }^{44}$. It was the same Holy Synod whose extremely politically restrained press outlet, “Църковен вестник”, in issue 48 of 1941 published Hitler's apologia, which came close to idolatry ${ }^{45}$. The same Synod, whose Metropolitan Archbishop Stefan, when the preparations for the transports began in 1943, called for the opening of the gates of monasteries and Orthodox churches to the Jews and made his own house available to Rabbi of Sofia. Another hierarch - Bishop Plovdiv Kirill (anarcho-communist in his youth, future patriarch of the Bulgarian Orthodox Church in communist Bulgaria) personally prevented the transport of Jews to, as it was said at the time, "Poland"... On the other hand, as Avramov proves, not all members of the Holy Synod, who formally supported its political decisions, behaved with equally noble attitude towards Jewish property, as exemplified by the connections between Bishop Vidyn Nikolai and the regime's Commissioner for Jewish Affairs.

Did therefore the Orthodox Church pass the test by declaring itself through its Orthodox hierarchs on the side of humanism ${ }^{46}$, and thus, in political action and practice, turning its back on the Gnostic temptation to dehumanize the alleged hylics? While maintaining an affirmative assessment of the Church's activities, Lea Cohen, quoted herein, draws attention to an aspect of the "Jewish question" which often escapes the researchers' attention. The author emphasizes the lack of coherence between the formal political affiliation, worldview and ethical choices of people. The biographies of those nationalist right-wing activists who committed themselves to protecting Bulgarian Jews from deportation to Treblinka, such as Dimitar Peshev (member of the establishment and speaker of the Bulgarian parliament, in 1940 and 1941 supporter of the introduction of the Law on the Protection of the Nation, sentenced to fifteen years in prison by the People's Court and released after one year), are illustrative.

Europe's recent history shows that every view of the world, every religion, including every Christian denomination at the level of anti-Gnostic self-interpretation, can be susceptible to Manichean seduction. The Bulgarian material confirms the banal idea that people's moral choices are not determined by their political or religious worldview, but often the discourses in which they are immersed, catalyzing radical behavior as a consequence of the binary divisions mentioned

\footnotetext{
${ }^{44}$ The Power of Civil Society in a Time of Genocide. Proceedings of the Holy Synod of the Bulgarian Orthodox Church on the Rescue of the Jews in Bulgaria 1940-1944, Sofia 2005.

${ }^{45}$ П., С вяра в Бог се побеждава световното зло, ЦВ 48, 1941, p. 1-2.

${ }^{46}$ D. Kalkandjieva, The Bulgarian Orthodox Church's Contribution to the Rescue of Jews in Bulgaria during WWII: A Model of Religious Tolerance \& Social Solidarity, https://www.academia.edu/2184932/ The_Bulgarian_Orthodox_Churchs_Contribution_to_the_Rescue_of_Jews_in_Bulgaria_during_ WWII_A_Model_of_Religious_Tolerance_and_Social_Solidarity.
} 
above. Brumlik, not sparing Protestantism, showed that by virtue of false rationalizations the mechanisms of the (quasi-)Gnostic exclusion for some time annihilate the cognitive dissonances that are troublesome at a given moment in history, but at the same time they are able to transform every human project into an instrument of violence and destruction.

As Barbara Skarga wrote in her book Człowiek to nie jest piękne zwierze [Man is not a beautiful animal]:

\begin{abstract}
Thought is torn, sometimes it supports evil or even creates it and constantly tries to fight it. The whole history of European culture is such a struggle, a fall into the unimaginable evil and an attempt to harness it. Evil like any other mystery, like what cannot be fully explained, like death, poses a strange attraction for our metaphysical spirit. In its clumsiness when faced with these mysteries, it is ready to propose a new way out, beyond good and evil, as if there were a world in which these ideas could be invalidated. ${ }^{47}$
\end{abstract}

The attitude towards the "Jewish question" in the interwar period and the years of World War II, full of internal contradictions and at the same time dominating in Bulgaria, becomes a challenge for history researchers in every era. In the context of the importance of the "Gnostic Bite" for the political and moral thought during the Nazi era in most European countries, the Bulgarian experience may become an interesting point of reference for comparative research into Judeophobia and antiSemitism, taking into account the structure of the national imageries of the individual imagined communities and their preferred strategies for generating hylics.

Translated by Katarzyna Gucio

\title{
Bibliography
}

\section{Primary Sources}

Avramov R., "Spasenie" i padenie. Mikroikonomika na dăržavnija antisemitizăm v Bălgarija 1940-1944 g., Sofija 2012.

CoHen L., Ti vjarvaš. Osem pogleda vărhu Holokosta na Balkanite, Sofija 2012.

Deportiraneto na evreite ot Vardarska Makedonija, Belomorska Trakija i Pirot, Mart 1943 g., vol. I-II, ed. N. Danova, R. Avramov, Sofija 2013.

Evreite po bălgarskite zemi. Anotirana bibliografija, ed. Ž. EskenaZI, A. KrisPin, Sofija 2002.

Genov R., Dizraeli, evrejstvoto i antisemitizmăt v Bălgarija, http://dialogueeurope.org/uploads/ JewsCol/Panel101.pdf [12 IX 2018].

\footnotetext{
${ }^{47}$ B. SKarga, O znaczeniu wymiaru metafizycznego w kulturze, [in:] Człowiek to nie jest piękne zwierzę, Kraków 2007, p. 24-25.
} 
GeZenKo I., Zakonodatelnata i izpălnitelnata vlast v izgraždaneto na antievrejskoto zakonodatelstvo 1940-1944 2..., [in:] Obrečeni i spaseni. Bălgarija v antisemitskata programa na Tretija rajh. Izsledvanija i dokumenti, Sofija 2007.

Hristov K., Ot nacija kăm rasa, "Училищен преглед” / "Učilišten pregled” 8, 1929.

ILČEv I., Mităt za San Stefanska Bălgarija kato "sveštena krava" na bălgarskija nacionalizăm, http://www.segabg.com/online/new/articlenew.asp?issueid=1486\&sectionid=8\&id=00003/ [22 I 2019].

Kalkandjieva D., The Bulgarian Orthodox Church's Contribution to the Rescue of Jews in Bulgaria during WWII: A Model of Religious Tolerance \& Social Solidarity, https://www.academia. edu/2184932/The_Bulgarian_Orthodox_Churchs_Contribution_to_the_Rescue_of_Jews_in_ Bulgaria_during_WWII_A_Model_of_Religious_Tolerance_and_Social_Solidarity [10 IX 2018].

Karavelov L., Zapiski za Bălgarija i bălgarite, Sofija 1930.

KRĂSTEva Z., Pravni aspekti na dăržavnata antievrejska politika v Carstvo Bălgarija (1940-1944 g.), Berlin.

Nedeleva P., Antievrejskoto zakonodatelstvo v Bălgarija prez Vtorata svetovna vojna, Sofija 2013.

Nedeleva P., Mjasto i rolja na evrejskata obštnost v bălgarskite zemi (ot osmansko vladičestvo do 30-te godini na XX v.), "Юридическо списание на НБУ” / "Juridičesko spisanie na NBU” 2, 2013, p. 33-58.

Oceljavaneto 1940-1944 (The Survival 1940-1944), ed. D. CoHEn, Sofija 1995.

P., S vjara v Bog se pobeždava svetovnoto zlo, “Църковен вестник” / "Cărkoven vestnik” 48, 1941, p. 1-2.

The Power of Civil Society in a Time of Genocide. Proceedings of the Holy Synod of the Bulgarian Orthodox Church on the Rescue of the Jews in Bulgaria 1940-1944, Sofia 2005.

RAjČEvski S., Bălgari i evrei prez vekovete, Sofija 2008.

TokušEv D., Antievrejskoto zakonodatelstvo i negovoto preodoljavane (1942-1945 g.), Sofija 2010.

VAzov I., Kăm propast, http://www.slovo.bg/showwork.php3?AuID=14\&WorkID=8693\&Level=1 [16 I 2019].

VAzov I., Svetoslav Terter. Ivan Aleksandăr, Sofija 1980.

VAzov I., Tăgite na Bălgarija, Bukurešt 1877.

Zakon za zaštita na nacijata, DV, No 16 ot $23.01 .1941 \mathrm{~g}$.

\section{Secondary literature}

ARENDT H., Eichmann in Jerusalem. A Report on the Banality of Evil, London 2006.

Benjamin W., On the Concept of History, New York 2009.

BRUMlik M., Gnostycy. Marzenie o samozbawieniu człowieka, trans. Ś.F. Nowicki, I. NowiCKA, Gdańsk 1999.

BRyкCzyński P., Gotowi na przemoc. Mord, antysemityzm i demokracja w międzywojennej Polsce, Warszawa 2017.

DĄBeK-Wirgowa T., O antynomii swoi - obcy z perspektywy butgarskiej, [in:] Kategorie peryferii i centrum w ksztaltowaniu się kultur narodowych, ed. T. DĄBEK-Wirgowa, J. WierzBICKI, Warszawa 1986.

Drzewiecka E., Herezja Judasza w kulturze (ponowoczesnej). Studium przypadku, Kraków 2016.

Dupré L., The Other Dimension. A Search for the Meaning of Religious Attitudes, Garden City 1972. 
The Experience of Faith in Slavic Cultures and Literatures in the Context of Postsecular Thought, ed. E. Drzewiecka, D. Sosnowska, Warszawa 2018.

Festinger L., A Theory of Cognitive Dissonance, Stanford 1957.

FLeCK L., Powstanie i rozwój faktu naukowego, Warszawa 1986.

GinZburg C., Il formaggio e i vermi, Torino 1976.

Israel J., Radical Enlightenment. Philosophy and the Making of Modernity 1650-1750, Oxford 2002.

Kunn T., The Structure of Scientific Revolutions, Chicago 1962.

Ogonowski Z., Socynianizm. Dzieje, poglady, oddziaływanie, Warszawa 2015.

Quispel G., Gnoza, Warszawa 1988.

Ricoeur P., The Symbolism of Evil, trans. E. Buchanan, Boston 1969.

Rusin B., Ekscesy antyżydowskie na ziemiach bułgarskich Imperium Osmańskiego w czasie wojny rosyjsko-tureckiej 1877-1878, http://apcz.umk.pl/czasopisma/index.php/SDR/article/view/ SDR.2016.1.01 [10 IX 2018].

Scatolla M., Teologia politica, Bologna 2007.

SKarga B., O znaczeniu wymiaru metafizycznego w kulturze, [in:] Człowiek to nie jest piękne zwierze, Kraków 2007, p. 10-25.

Szwat-GyŁYbowa G., Haeresis bulgarica w bułgarskiej świadomości kulturowej XIX i XX wieku, Warszawa 2005.

Szwat-Gy£ybowa G., Playing Catch up: The Notion of Needing to Accelerate a Country's Progress Towards a Civilised Paradise - The Bulgarian Version, "Slavia Meridionalis" 14, 2014, p. 310-328.

TAmir V., Bulgaria and Her Jews. The History of a Dubious Symbiosis, New York 1979.

TAubes J., Apokalipsa i polityka. Eseje mesjańskie, Warszawa 2013.

Todorova O., Evreite v bălgarskata slovesnost ot načaloto na XIX vek do Osvoboždenieto, http://www. librev.com/index.php/discussion-bulgaria-publisher/1759--ix- [12 IX 2018].

Todorova O., The Nineteenth-Century Bulgarians' Perception of the Jews, "Études balkaniques" 1995.3/4, p. 40-41.

Todorova O., Obrazăt na "nečestivija evrein" bălgarskata knižnina ot XVIII - načaloto na XIX vek $i$ văv folklora, "Byzantinische Forschungen. Internationale Zeitschrift für Byzantinistik" 3, 1994, p. $10-21$.

Todorova O., Mirčeva K., Familijata Milingen i bălgarite prez tretata četvărt na XIX vek, https://www.marginalia.bg/aktsent/familiyata-milingen-i-balgarite-prez-tretata-chetvart-nahih-vek/ [12 III 2018].

TokArska-Bakir J., Legendy o krwi. Antropologia przesądu, Warszawa 2008.

TokArska-Bakir J., Pod klątwa. Społeczny portret pogromu kieleckiego, Warszawa 2018.

Voegelin E., Od oświecenia do rewolucji, Warszawa 2011. 


\begin{abstract}
The article poses a research question, important not only in the studies on (neo-)gnosticism, concerning the relationship between the gnostic strategies of interpreting the world (and especially its typical rules of classifying people, based on the externalization of evil) and the tendency to construct a figure of "hylic" as a person embodying evil, and thus "unworthy of life". In this context, the author is interested in the dynamics of the relationship between the religious worldview declared by the authors, the one they actually profess, and their attitude towards the so-called Jewish question. Bulgarian material, which is a case of a particular kind of aporia, cognitive dissonances emerging due to tension between the pressure of cultural stereotypes, pragmatic (economic), religious, parareligious and humanistic thinking, has been analyzed on the basis of post-secular thought. The investigator posits that Bulgarian culture, despite the "economic" anti-Semitism that exists within it, did not produce a figure of a Jew the hylic that absorbs all evil and that could be inscribed (as is the case in popular Polish culture, among others) in every troublesome local political and symbolic context.
\end{abstract}

Keywords: Gnosis, Orthodox Christianity, anti-Semitism, Bulgarian culture, cultural transfer

Grażyna Szwat-Gyłybowa

Polish Academy of Sciences

Institute of Slavic Studies

ul. Bartoszewicza 1b m. 17

00-337 Warszawa, Poland gszwat@ispan.waw.pl 